\title{
Womanism and Patriarchy in Chimamanda Adichie's Purple Hibiscus.
}

\section{Stanley Ordu}

Researcher, Chaps Multi-Concept Ltd. Plot 6, Osichi Street off Ikiri, Road, Omoku, Nigeria. Mail Id: stanleyordu12@gmail.com | ORCID ID: 0000-0003-2137-2842

\begin{abstract}
Womanism, as a subset of African feminism, provides a framework for assessing the works of African female authors critically. The work of Chimamanda Adichie, a Nigerian female writer and author of Purple Hibiscus, is examined using Ogunyemi's womanist philosophy. Through thorough examination, a womanist reading of this novel aims to find the many and related ways this female author articulates and demonstrates womanist ideology in the above-mentioned work. The experiment's purpose was to examine if this female author's womanist ideas persisted. The findings of this study are based on a careful reading of the text, with an emphasis on literary elements including characterization, narrative approach, tone, mood, and setting. Adichie's work clearly tends to resist and usurp patriarchy, as seen by the novel's analysis. Purple Hibiscus by Chimamanda Ngozi Adichie echoes womanist longing as well. On the other side, the author tends toward the ultimate womanist ideal of union and survival for man, woman, and kid.
\end{abstract}

Keywords: Womanism, Patriarchy, Feminism, Black Women.

\section{Introduction}

Chimamanda Adichie's Purple Hibiscus is a feminist novel that advocates feminism. Men, women, and children are all included in this gospel that is geared to African-Americans' needs. It also looks at African women's problems holistically, taking into consideration racial, cultural, national, economic, and political challenges, as well as sexist ones, with the ultimate goal of ensuring the survival and unity of the black/African community. Adichie embraces this womanist gospel in Purple Hibiscus, tackling not just sexist treatment of women, but also racial issues, national politics, patriarchal culture, and economic conditions. In these two volumes, the multi-faceted perspective to women's struggles underscores the need of men, women, and children working together to survive in the end. 
Resistance to patriarchal conduct, as well as the idea that women may live their lives as they like and be responsible for their own livelihoods and destinies, are popular themes among African female authors. The female novel, as a protest book against patriarchy, depicts inequalities and injustices done on women by patriarchal traditions, whether Christian, Islamic, or indigenous. These books are both a protest against patriarchal power and a representation of a self-sufficient woman. Feminist values that promote independence, unity, and survival are emphasized heavily by African female authors. Africa is an African continent.

Female novelists like as Ama Atta Aidoo, Bessie Head, Calixthe Beyala, Mariama Bà, Buchi Emecheta, Tsitsi Dangarembga, and, most recently, Chimamanda Adichie have pioneered the way.

\section{Theoretical Framework}

This article is about Chimamanda Adichie, a West African womanist author who uses feminist philosophy to express her concerns. Womanist examination of these two writers' works is permitted since womanism is an African feminism that stresses male and female survival, as well as cooperation and complementarity, as essential to Black/African feminism. It could be argued that Ogunyemi's womanism is just one of many forms of African feminism, such as motherism, a theory proposed by Catherine Acholonu that puts motherhood, nature, nurture, and environmental respect at the center of its theorizing; and'stiwanism,' which comes from the acronym "STIWA," which stands for "Social Transformation Including Women in Africa," developed by Molara Ogundipe-Leslie; and'stiwa As a result, womanism is a social change approach based on the experiences of African, African American, and other women of color. African feminism, on the other hand, is exclusively concerned with the experiences of African women and how to bring about societal change by including both men and women. Womanism is thus useful in the study of these two West African works since it can be used in both an African and an African American context without generalizing women's experiences.

"The basic difference between feminists and womanists is thus what each detects in patriarchy and what each feels may be fixed," writes Ogunyemi in her book "Womanism: The Dynamics of the Contemporary Black Female Novel in English" (69). She distinguishes radical feminism from womanism in this way. According to radical feminism, sexism is the only patriarchal system that oppresses and oppresses women, with women meaning white middle-class educated women. Of course, black women are exempt from this. As a result, radical feminists regard confronting and changing sexism as a win for all women in all cultures across the world. Aside from this, radical feminism seeks to create a separatist ideal society devoid of male authority.

The treatment of black and African-American women isn't the only aspect of womanism. When asked about the situation of women's writing in South Africa, Beata Lipman, a white South African journalist, replied, "Racism is a more important concern than sexism" (Ogunyemi, p. 67). Lipman's remark provides a broad yet culturally specific definition of womanism, incorporating racism and sexism as fundamental elements of black feminism, and particularly womanism. Womanism is 
concerned with more than sexism and racism; it also addresses cultural, national, economic, and political factors in the fight against repressive patriarchal systems. As a result, the womanist sees patriarchy as including racism, cultural oppression, national oppression, economic oppression, and political oppression, in addition to sexism.

The oppression of black and African people by white patriarchal institutions is well-known.

The womanist confronts patriarchy as a constraining reality as a woman in relationship to her Black/African male counterpart, and as a person oppressed and exploited politically and economically by the white race.

Furthermore, rather than exclusivity, womanism promotes a sense of wholeness and oneness that encompasses men and women, as well as children. As opposed to radical feminism, it is not separatist or anti-male.

Womanism imitates African feminist ideology by emphasizing African women's oppression, and the two approaches to addressing women's oppression are complementary. In the sense that African feminism implies female independence from oppressive male control, as well as, if necessary, cooperation with men, whereas (Ogunyemi, 2003) and (Walker, 1984) present a womanism targeted at both male and female universal survival. This viewpoint runs counter to radical feminists' belief that men and women are determined by biological and psychological differences. According to Firestone, women are oppressed since men are in charge of their output (Bhasin, pp. 25). The radical feminists' notion of the sex class system as the sole source of women's oppression restricts study into the specificities of women's oppression across cultures (Bhasin, $p$. 25). Brownmiller also thinks that in order to maintain their dominance and superiority, men utilize their power to rape, intimidate, and manipulate women. Other radical feminists believe that men are a ruling class that maintains power by direct violence that gets institutionalized through time due to their nature and/ or psychology.

(Bhasin, p. 26). Amazonian feminism, on the other hand, emphasizes physical equality and combats gender stereotypes and prejudice against women based on the belief that women should look, seem, or behave in a meek, weak, and physically powerless manner. Amazon feminism promotes and examines a picture of heroic femininity, rather than presuming that particular characteristics or interests are intrinsically masculine (or female). According to Amazon feminists, all women have the same physical capabilities as all men (amazoncastle.com).

In this argument, Bell Hooks presents the following case for patriarchal domination and other forms of sexism's oppression of black communities:

Every Black person concerned about our collective survival must acknowledge that sexism is a destructive force in Black life that cannot be effectively addressed without an organized political movement to change consciousness, behavior and institutions. What we need is a feminist revolution in Black life. But to have such a revolution, we must first 
have a feminist movement. Many Black folks do not know what the word feminism means. They may think of it only as something having to do with white women's desire to share equal rights with white men. In reality, feminism is a movement to end all sexism and sexist oppression. The strategies necessary to achieve that end are many. We need to find ways to address the specific forms that sexism takes in our diverse communities (Hooks, p.124; in Elizabeth Torfs,p.21).

According to the preceding response, applying mainstream feminism to the concerns and predicament of black women is inappropriate, especially since black women perceive that mainstream feminism is largely for Eurocentric and ethnocentric white women.

According to Ogunyemi, she devised her feminist theory without realizing that Alice Walker had previously proposed a similar concept. Walker's feminist theory encompasses both the flaws and the promise of black feminist criticism. It demonstrates black feminists' willingness to recast the sexual debate around white and black women's cultural distinctions. The fundamental principles of Walker's theory of womanist epistemology are daring, woman-centeredness, and entire (some)ness or community-centeredness. These three essential feminist principles assist in the development of a feminist resistance framework to patriarchy (Jita Allan, p. 6). Walker's feminist philosophy is a rebuttal to radical white feminist theory and practice.

According to Margaret Drabble, (1971) Womanism is cross-cultural:

The multidimensional goal of Womanism is a gender-free Pan Africanism - the worldwide unity of black people under the wise leadership of men and women. This is not the same as a white writer's obsession with a Separatist, lovely living separate from the...world. ( Jita Allan, p.7) Unlike Drabble, Patricia Hill Collins is influenced by womanism, a "humanist worldview" rooted in black women's struggles against oppression. Hill Collins embodies the womanist notion of "commitment to the survival and fullness of all humans, male and female," a reoccurring theme among African women intellectuals (Jita Allan, p. 8). She lays the groundwork for the future.

Womanist connections with women like Anna Julia and June Jordan, whose "speech and acts resonate with a strikingly comparable sense of oneness of all human beings," according to Womanist (p. 8).

For the sake of this study, we will employ Ogunyemi's womanist theory to build a womanist interpretation of Purple Hibiscus. She captures womanism's focus in the following phrases:

Womanism is black-centered and accommodationist. It believes in women's freedom and independence, much as feminism does; but, unlike radical feminism, it wants true unity among black women, men, and children, and will try to change men's sexist beliefs (In Maduka, p. 14). 
She believes that womanism is the weapon that would unite black/African women in their fight for liberation, ultimately leading to men learning that women are human beings like men by fighting men's oppressive thinking and behavior. It, on the other hand, embraces both men and children and tries to unite them.

A womanist writer, Ogunyemi believes, acknowledges the importance of infusing racial, cultural, national, economic, and political components into her thought, in addition to her grasp of sexual issues (Ogunyemi, p. 64). Because of her "racial and sexual problem," one of them is a womanist (Ogunyemi, p. 79). Womanism is therefore at the heart of African women's racial, sexist, political, cultural, and economic reality. It advocates for African women's empowerment.

It takes a comprehensive perspective to patriarchy and female enslavement, dismissing sexism as the main source of female opposition to male domination.

She inspires the intelligent black woman writer to acknowledge black people's powerlessness in the face of white patriarchal culture, and she empowers her male counterpart because she believes in him; as a result, the womanist writer's books end with integrative images of male and female worlds (Ogunyemi, pp. 68-69). The womanist author's focus isn't on equal rights for black men because she aspires to greater heights. Rather of focusing on female transcendence, she brings together all of the world's black families in order to attain black transcendence (Ogunyemi, p. 69). The distinction between radical feminism and womanism is articulated by Ogunyemi:

If radical feminism's ultimate objective is to live a separatist ideal separate from the men's world, womanism's ultimate goal is to unite black people all over the world under the enlightened supervision of men and women (p. $\underline{72})$.

A womanist perspective acknowledges the positive features of black life while also raising concerns about black African women's humanity.

Ogunyemi believes that her understanding of womanism is akin to Alice Walker's, i.e., a phrase that alludes to a teen girl's metamorphosis as she comes to grips with her gender identity. A womanist, according to her, is someone who is dedicated to the survival and well-being of all humans, male and female (p. 72).

Black Womanism is a worldview that honors black culture, upholds black values, and presents black femininity in a positive manner. It's about the struggle for black sexual power, as well as world power's persecution of black people. The ideal state of black unity is one in which every black person has some power and may be a brother, sister, father, or mother to someone else. Its goal is to communicate the energy of completeness and healing that may be found in womanist literature's uplifting, integrative ends (Ogunyemi, p. 72).

The anti-patriarchal position of feminist writers is reflected in their representations of feminists. Families are important to womanist writers, but not the nuclear family as we know it in the West, 
but rather the black extended family. As a result of the desire to develop autonomous black women, womanist writers infuse their works with a positive attitude that is full of female success. They also look at the historical and current ties that exist between African-Americans and Africans.

In literature, womanist protagonists are shown as pleasant co-wives with hidden husbands who cooperate for the greater good. It's also possible that the black mad lady in black women's fiction realizes in her subconscious that she needs to survive since she has people who rely on her and don't have any other options. She constantly recovers and helps others after exerting considerable effort. The black woman's communion with the rest of society is developed as a result of each womanist character's mental upheaval (in the womanist book), an accord that symbolizes the black manner of authenticity and transcendence. As a result, crazy is reduced to an isolated incident that occurs prior to spiritual growth, healing, and integration (Ogunyemi, p. 74). Activism by women of color

Polygamy is portrayed as a positive practice in fiction because cultural demands take precedence over sexual politics. Feminist writing might be influenced by matrilineal and polygynous societies. In womanist literature, bad males are exterminated on a regular basis so that men and women might live in peace. Furthermore, rather than sexism, ostracism and ethnicism promote the development of strong women (Ogunyemi, pp. 75-76). Womanist authors likewise prefer to write about life as it is, rather than how it should be. As a result, womanist authors are more concerned with survival ethics than aesthetics of life.

The devotion of these two womanist writers to two values that respect the survival of men, women, and children, as well as compassion for human suffering, will be examined in Adichie's Purple Hibiscus.

\section{Literature Review}

Chimamanda Adichie's and Chinua Achebe's writings have been compared by certain academics. According to Kwame Dawes in his review "Nigeria," Purple Hibiscus may be seen as yet another volley against colonialism and the patriarchy that has been portrayed in much of West African writing. In Purple Hibiscus, he tells the story of a mute voice who has been traumatized by a tyrannical Catholic father who abuses his family; a father who is completely devoted to Western colonial principles. Rather, his dominating and aggressive attitude, which may possibly be regarded end results of colonialism, is what motivates him to abuse his wife and children, despite the fact that patriarchy is a legacy of colonialism. "Things began to come apart at home when my brother, Jaja, did not go to communion and Papa tossed his heavy missal across the room and destroyed the figurines on the etagere," Adichie writes in the first phrase of her novel Purple Hibiscus. Adichie's work opens with Achebe's enormous story of a "clash of cultures," as Dawes points out. Eugene Achike's dogmatic Catholicism, which is replete with abuse and hypocrisy, is what really counts at the end of the story, according to Dawes. The structure of Catholicism, as well as the problems of patriarchy that it involves, are important topics in the work. 
According to Dawes, Adichie connects ideological and political topics through metaphor and symbolism. The finest African writing is concerned with these concerns. Purple Hibiscus has a colorful aesthetic and an appealing voice that, like Things Fall Apart, echoes issues such as patriarchy. Dawes' piece uses Purple Hibiscus and Things Fall Apart to emphasize the cruelty and violence that has defined African nations and families as a result of patriarchy.

Heather Hewett looks at a new generation of Nigerian authors who are breaking the silence of repressive governments. "The coming of age of the trauma that leads to calamity in a family," she says in her review, "Finding Her Voice." This is because a father who seeks to dominate his family by subjecting them to a great deal of violence causes the family to go through a period of trauma during which he dies, his son is imprisoned, and his daughter and wife must find a way to heal the wounds that will not heal because the father sought to dominate according to his own desires.

Hewett also emphasizes Dawes' notion that Purple Hibiscus opens similarly to Things FallApart. The way Adichie divides the family unit into political and religious forces under the sway of a dominating father, she argues, is where the similarities between the two works may be found. She believes that Achebe's tale in Things Fall Apart is set in a time when Christianity has arrived in Igboland, but Adichie's story in Purple Hibiscus begins during Nigeria's independence fight, when Christianity has taken root. Hewett's piece also addresses the issue of a "god-like" parent who has complete authority over his children and wife. Purple Hibiscus is about Kambili's existence, according to Hewett, and the limits she has as a daughter of a patriarchal father, as well as the new ways of living she learns.

She discovers at her Aunty's place. Kambili musters the confidence to expose her domestic experiences, which mirror the realities of patriarchal Nigerian culture. These events resemble those described in Things Fall Apart, especially in terms of the elders' role and the tragic hero, Okonkwo.

Mas Khan's Purple Hibiscus research, titled "No Hope in Nigeria," is much different from Dawes and Hewett's. According to the review, Purple Hibiscus is the story of Kambili, a fifteen-year-old whose country, Nigeria, is in the midst of political crisis. Her father is a tyrant who abuses his wife and two children. Khan investigates the coup in Purple Hibiscus, which causes a transformation in Kambili's and her brother Jaja's environment. They've gained a wealth of knowledge from their aunt Ifeoma. Kambili, like her brother Jaja, "finds herself," and they both come from a home that encourages dispute. "No Hope in Nigeria" explores the political turmoil and corruption that afflicts countries like Nigeria. According to Khan, the narrative contains a compelling plea for religious tolerance. According to Khan, who defines his job as "typically depressing," the destiny of the family ultimately dictates the fate of the country. Finally, Khan's paper advises that Purple Hibiscus be widely read in the rich first world in order for issues of poverty and migration to be regarded in a fresh light. 


\section{WOMANISM AND PATRIARCHY IN PURPLE HIBSCUS}

\section{The first sentence of Purple Hibiscus reads:}

Things started to fall apart at home when my brother, Jaja, did not go to communion and Papa flung his missal across the room and broke the figurines on the étagère (p. $\underline{3})$.

The work's first line is a feminist manifesto. It's also a patriarchal comment from Achike. "Masculinity encompasses a wide range of features, including physical strength, sexual and functional duties, social position, emotional characteristics, and intellectual talents," according to Loum (p. 273). In this opening statement, the reader is introduced to Achike's use of physical might and social power to compel his son to follow his prescribed male instincts. Achike's wife, Beatrice, his son, Jaja, his daughter, Kambili, and even his sister, Ifeoma, are all subject to religiously masculinist societal control. In this circumstance, he's trying to figure out why Jaja isn't going to Mass. The Achike family's breakdown is the fault of Jaja. Despite the fact that this term portrays Jaja's outgoing personality, their aunty, Ifeoma, is the real reason for Jaja's macho challenge to his father. After Jaja's disobedience of his father, Kambili remains in bed, letting her mind to wander back in time:

I lay in bed after Mama died, allowing my thoughts to travel back to the years when Jaja, Mama, and I spoke more with our hearts than with our tongues. At least till Nsukka. It all began in Nsukka, when Aunty Ifeoma's modest garden next to her flat's door began to lift people's moods.

silence. Aunty Ifeoma's experimental purple hibiscus reminded me of Jaja's bravado: uncommon, fragrant, and tinted with liberty..." (p.15)

It's worth noting that Aunty Ifeoma's democratic climate in Nsukka has influenced many people's lives, not only Jaja's. The reader meets a confident Kambili, whose timidity at the beginning of the story has given way to "A freedom to be, to" (p. 16).

I study Adichie's brilliance in compressing all of her womanist ideas into the first chapter of the novel before turning my attention to Kambili's evolution from a naive, innocent girl to a responsible, courageous girl-woman.

\section{Womanist Concerns for Political, Social, Economic, and National Issues in Nigeria by Chimamanda Ngozi Adichie}

"Breaking Gods, Palm Sunday," Adichie writes in the first chapter of Purple Hibiscus. This term represents the triumphal entry of Jesus Christ into Jerusalem. The first half of the title refers to how Achike destroys his missal, which is a sign of his Catholic faith, together with his figurines, which 
are a source of solace for her, when he physically abuses her. The shattered figurines and the ruined missal are the first signs of the Achike household's demise. It's also a kind of despotism, bolstered by Catholic dogma and faith. Kambili speculates, "Perhaps Mama anticipated the necessity to intervene."

"... everything came tumbling down, not just the figurines, as Papa flung his missal at Jaja" (p. 15).

\section{The Womanist Metamorphosis of Kambili}

The importance of Adichie's subtitles in the plot should not be overlooked. "Speaking with our Spirits; Before Palm Sunday," the second chapter of Purple Hibiscus, chronicles the events leading up to Jaja's insurrection on Palm Sunday. Kambili has grown from a "timid, girlish, and silent" sixteenyear-old to a bold, outspoken, and passionate girl-woman by the end of the novel. OgagaOkuyade examines "the developing process of the heroine, Kambili, as she strives to make her mouth work inside the authoritarian setting of her father's home" in his article "Changing Borders and Creating Voices: Silence as Character in Chimamanda Adichie's Purple Hibiscus." "At the beginning of the tale, the protagonist is embroiled in a crisis with religious and familial stakes; she appears to be a simple observer and victim," Okuyade (2009) writes, "but as the novel meanders towards its conclusion, she rediscover her voice and role in the household after her awakening" (p. 1).

\section{Nsukka as a Womanist Symbol of Change and Audacity}

Ifeoma's residence in Nsukka plays a number of roles in Kambili and Jaja's metamorphosis. Ifeoma's liberalism and fiery personality are at the foundation of every shift in Kambili and Jaja's life. By poisoning Achike, Beatrice just completes the final barrier of the alleged coup d' etat in Achike's family.

Kambili's initial meeting in Nsukka, while she still has her eyes closed after Auntie Ifeoma has completed saying grace, begins the womanist shift that is engendered in Purple Hibiscus. "We don't say Mass in the name of grace like your father," her Aunty says with a grin (p. 119). The most important argument Kambili makes, however, has little to do with the differences in grace between Ifeoma and Achike. She says,

All around me, laughter resonated. Everyone said what they felt, frequently without anticipating or receiving a response. My cousins looked to be unable to stop talking. We used to converse with purpose at home, especially around the table, but they appeared to just talk and talk and talk.( $p$ 120)

Kambili's reaction to the events at the dinner table is nearly unbelievable, as she psychologically withdraws from the situation. Ifeoma's question about whether she enjoys the cuisine is the only thing that shocks her. Ifeoma realizes that Kambili and Jaja have been living in a family where the only auditory communication they are aware of is domestic quiet. "I had the sensation that I wasn't there," Kambili says, "that I was merely viewing a table where you could say anything to anybody 
at any time, where you could breathe as you pleased" (p. 120). This is in stark contrast to Achike's household, where economic talks predominate. When Jaja and Kambili sit down to eat at their father's house, they are limited to three phrases of gratitude to "God, Papa, and Mama" or a comment advertising one of Achike's factory's products. It astounds her to hear terms that aren't used for any reason yet are acceptable to her cousins. Kambili's stuttering speech begins to change in this way, however it takes her some time to get the bravery to speak what she really wants to say without seeking approval from others. As a result, Kambili compares her Aunty's job to that of a coach who emphasizes discipline as a key to success while encouraging teamwork, unity, consensus, and optimal talent usage. Ifeoma looks at her children with a "proud-coach-watchingthe-team mindset" if there is laughter and open communication, she says (p. 131). Ifeoma prays for laughter, something her father would not, as Kambili eventually discovers. Chimamanda Ngozi Adichie's Commitment to Addressing Sexism in Nigerian Society

Achike's sexist treatment of his wife, Beatrice, and how she, along with Ifeoma, replies.

Adichie's feminist commitment to fighting sexism, or uneven treatment of women just because they are women, is demonstrated in the following ways:

\section{a.Misogynistic Beatrice and Other Female Characters: Achike's Attitude}

b.Patriarchal Resistance and the Subversion of Sexism

c.Female Bonding and Mutual Acceptance

Achike's Misogynistic Attitude Towards Beatrice and Other Female Characters.

Achike's sexist behavior against his wife is part of a patriarchal system dominated by males. The "rule of the fathers" is how patriarchy is described (Okuro, p. 523). This statement expresses two ideas: a father is acknowledged as the family's ultimate authority and ruler, and a father is regarded as the family's ultimate authority and ruler. As king, he is at the heart of the family, with his wife and children on the perimeter. Father is "One," while wife and children are "Others," as Simone de Beauvoir put it (Selden, Widdowson \& Brooker, p. 127). Achike's "Othering" is servile, exhibiting contempt for his wife's humanity.

Kate Millet defines patriarchy as "an institution used by men to subordinate females, children, and even other men, or to treat females, children, and other men as inferior humans by exercising their power in civil and domestic life to constrain wives and children," according to her book Sexual Politics (1969). (Section 131) Selden, Widdowson, and Brooker are three of the most well-known authors of the twentieth century. Achike is a patriarch in the sense that he rules over his female wife and children. Gwen Hunnicut (2009) elaborates on this topic, writing, "The essential notion of patriarchy relates to systems of male dominance and female submission" (p. 553). Within the scope of this notion, patriarchy is described as a representation of gender hierarchies, domination, and power systems (gender as a socially created system). In the Achike household, there is a gendered 
hierarchy that must be upheld. He is the head of the household and has the last say, while his wife and children, particularly his wife, must serve without question. As a result of the Achike family hierarchy, he has authority and influence over his wife and children. The question is how Achike will utilize his power to keep his family under control. The patriarchal power is used to "directly or indirectly constrain women in civic and domestic life," according to Millet. However, in Purple Hibiscus, the patriarch's power is utilized to limit youngsters and men, as well as his wife and daughters. The patriarch's dominance is instantly demonstrated in Achike's family by physical aggression (such as beating his wife) and by compelling his wife and children to believe the same way he does. As a result, Achike does not need to be a violent patriarch, because domination and submission require not only physical brutality but also emotional, mental, and spiritual pain. Achike resorts to physical attack to maintain his sexist mindset towards his physically inferior wife.

\section{Resistance against Patriarchy and the Subversion of Sexism}

The patriarch, Achike, uses Catholicism to govern and dominate his dominion. As a result, his son, Jaja, feels it's perfectly OK to exploit his father's Catholicism to justify rejecting any and all forms of chaotic dominance. The arguments intended to dispute Jaja's reasons for not attending the communion ritual intensify his hesitancy to accept communion. Most secular objects are reviled in Christianity. Whether deliberately or unwittingly, Jaja takes advantage of this deep faith by downplaying the relevance of Christianity.

Element of worship When his father questions him about why he refuses to take communion, he responds in a way that displays his perversion and devaluation of Christian doctrine. Jaja refers to the "host" as a "wafer," which Achike despises because it misses the essence and purity of Christ's flesh. Jaja completes his act of subversion when he says that the "host" makes him nauseated. "You cannot stop embracing the body of our Lord Jesus," Achike responds religiously, "because you understand it's the end" (p. 6). The significance of this setting in the novel's first few chapters is to demonstrate how the patriarchal system may be overturned when oppressed people are pushed to the point where the only acceptable response is to destroy authority. The statement "everything started to fall apart at home" by Adichie, which is also tracked by Beatrice, Achike's wife, through Kambili's narration, signifies a breakdown of patriarchal power inside the Achike household.

Beatrice's defiance of the patriarch's sexist viewpoint is more nuanced than Jaja's. It might be a reflection of her lack of confidence in challenging the status quo, which is a quality she shares with Jaja. She plans to poison the patriarch's food and drink in order to assassinate him in a non-lethal manner. In contrast to Jaja's disobedience, which is easy, this is notable. This reminds me of Kate Millet's definition of patriarchy: "power is employed, directly or indirectly, to restrict women in civic and domestic life" (Raman Selden, p. 131). Discrimination, disdain, insult, control, exploitation, oppression, and violence, according to Bhasin, are all examples of direct or indirect patriarchal oppression directed against women (p.3). Violence is the patriarch's principal patriarchal technique in Achike's household. Beatrice, you're done. 
The patriarch is poisoned by frustration and desire to live until he is discovered dead in his office.

\section{Acceptance of women and the formation of bonds between them.}

In the Igbo cultural worldview, the expression "nwunye, m," which means "my wife," conveys a reciprocal feminine relationship and acceptance. In just two pages, this word appears four times (pp. 72-73). Ifeoma addresses Beatrice by her first name, Beatrice.

Kambili's father's hatred for such rites, which he refers to as "relics of bad traditions," is set against the backdrop of a lady calling her brother's wife "my wife." "Papa declared it was the leftovers of terrible culture, the belief that it was the family, not the guy alone, who married a bride..." says Kambili. ( p. 73 )

Ifeoma's faith in her ancestors demonstrates that womanism does not reject culture, but rather uses it to enhance women's empowerment and well-being. This cultural paradigm, on the other hand, demonstrates that womanism is about recognizing a collective body of women against patriarchal domination, rather than individualized female desires of freedom, self-fulfillment, and pleasure. "It demonstrates that she embraces me since I am your father's wife and her wife," Beatrice explained. The following are some of the points that (p. 73) emphasizes: Ifeoma adores Ifeoma, and she adores her (in a non-sexual sense); they're fighting Achike's sexist behavior and patriarchal society. It also specifies that Ifeoma and Achike both have husband responsibilities, and that the marriage will prosper via partnership, masculine respect, equal treatment, and a rejection of any abusive tendencies. Ifeoma's acceptance of Beatrice as her brother's bride and a woman who deserves respect is symbolized by the phrase "Nwunye, m."

\section{Conclusion}

Womanism is an African feminist subgroup that delves deeply into the works of African female authors. It encompasses cultural, racial, national, economic, and political concerns, as well as sexism ones, because its views are centered on communalism rather than individuality.

Adichie is seen as a feminist author in this study's assessment of her book Purple Hibiscus. Their feminist ideals and ideas, on the other hand, are very different. Both the womanist goal of survival and the patriarchal culture's challenge are important to Adichie. While defying patriarchal authority, she imbues her female characters with strength, persistence, and courage. Kambili, Jaja, and Beatrice are given a second chance at life, a rebirth, in the ultimate analysis of her story, demonstrating how womanist hope pervades her agenda. 


\section{References}

Adichie, ChimandaNgozie. Purple Hibiscus. Victoria Island, Lagos: Farafina. (2006).

Bhasin, Kamla. What is Patriarchy? Inderpuri, New Delhi: Raj Press. (1993).

Dawes, Kwame. Review: “Nigeria." World Literature Today Jan-Apr 2005:84. Jstor 21

December 2009 http:/ / ezproxy.ug.edu.gh:2061/stable/40138802

Hunnicut, Gwen. “Varieties of Patriarchy Against Women: Resurrecting 'Patriarchy' as a

Theoretical Tool” Violence Against Women 2009 15: 553-569. SAGE Publications. Balme

Library, University of Ghana. 22 October 2010.

http://vaw.sagepub.com/content/15/5/553.refs.html

Khan, Mas. Review: “No Hope in Nigerian” Fortnight Jan 2005: 21. Jstor 22 December 2009.

http://www.jstor.org/stable/25561378

Ogundipe-Leslie, Molara. "Moving the Mountains, Making the Links." Recreating Ourselves: African

Women and Critical Transformations. Trenton, New Jersey: Africa World Press, Inc. (1994).

"Stiwanism: Feminism in an African Context." African Literature: An Anthology of Criticism and

Theory. Eds. Tejumola Olaniyan \&AtoQuayson. Malden, MA: Blackwell, 2007.pp.543-550.

Ogunyemi, ChikwenyeOkonjo. "Womanism: The Dynamics of the Contemporary Black Female

Novel in English." Signs, 11:1 (1985: Autumn) p.63

Okuyade, Ogaga. "Changing Borders and Creating Voices: Silence as Character in Chimamanda

Adichie's Purple Hibiscus" March 2009: 247. 22 December 2009.

http://www.panafrican.com/docs/vol2/2.9_Changing Borders_andCreating_Voices.pdf

Ong'wenOkuro, Samuel. “Our Women Must Return Home: Institutionalized Patriarchy in Colonial

Central District, 1945-1963" Journal of Asian and African Studies 2010 45: 522-532.

http://jas.sagepub.com/content/45/5/522.refs.html

Selden, Raman., Widdowson, Peter \& Brooker, Peter. (1997). A Reader's Guide to Contemporary

Lietrary Theory. $4^{\text {th }}$ ed. Hemel Hempstead, Hertfordshire: Prentice Hall/Harvester Wheatsheaf

Torfs, Elizabeth. (2007-2008). Alice Walker's Womanism: Theory and Practice. Dissertation. Catholic

University of Leuven.

Stanley Ordu is a Researcher working at Chaps Multi-Concept Ltd. Plot 6, Osichi Street off Ikiri, Road, Omoku, Nigeria. 